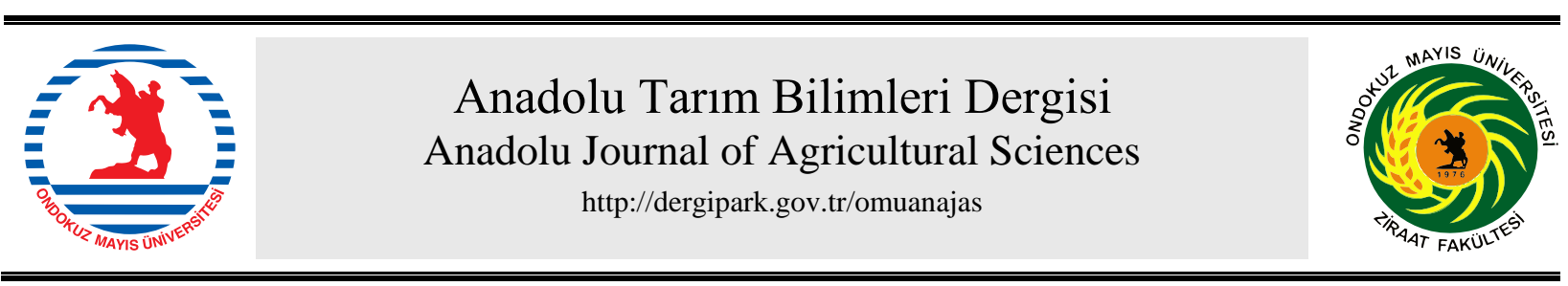

Araştırma/Research

\section{Kadmiyumun Küçük Balmumu Güvesi Larvalarında Protein, Lipit ve Karbohidrat Miktarları ile Etkileşimi}

\author{
Yeliz Y1lmaz ${ }^{\mathrm{a}}$, $\odot$ Nevran Eylem Akman Gündüz ${ }^{\mathrm{a} *}$ \\ ${ }^{a}$ Ondokuz Mayıs Üniversitesi, Fen-Edebiyat Fakültesi, Biyoloji Bölümü, Samsun, Türkiye \\ *Sorumlu yazar/corresponding author: gunduzeylem@gmail.com
}

Geliş/Received 25/02/2021 Kabul/Accepted 24/05/2021

\begin{abstract}
ÖZET
Kadmiyumun küçük balmumu güvesi, Achroia grisella Fabricius, 1794 (Lepidoptera: Pyralidae) larvalarının protein, lipit ve karbohidrat miktarlarına etkisi laboratuvar koşullarında araştırılmıştır. Larvalar kadmiyumun üç farklı konsantrasyonu (50, 100 ve $200 \mathrm{mg} \mathrm{kg}^{-1}$ besin) ile kontamine edilmiş yapay besin ortamında yetiştirildi. Kontrol grubundaki böcekler bal peteği (200 g), kepek (860 g), gliserol (300 ml), bal $(150 \mathrm{ml})$ ve saf su $(150 \mathrm{ml})$ içeren ancak kadmiyum içermeyen besinle beslendi. Böceklerin tümü $25 \pm 2{ }^{\circ} \mathrm{C}$ sıcaklık, $\% 60 \pm 5$ bağıl nem ve $16 \mathrm{~A}: 8 \mathrm{~K}$ fotoperyot koşullarında yetiştirildi. Biyokimyasal analizler için son evre A. grisella larvaları tartılıp ayrı mikrosantrifüj tüplerine konularak -20 ${ }^{\circ} \mathrm{C}^{\prime} \mathrm{de}$ tutuldu. $\mathrm{Bu}$ çalışmanın sonuçları 50 ve $200 \mathrm{mg} \mathrm{kg}{ }^{-1}$ kadmiyum konsantrasyonlarında kontaminasyonun larvaların protein seviyesinde önemli bir düşmeye neden olduğunu göstermiştir. Karbohidrat miktarı sadece $50 \mathrm{mg} \mathrm{kg}^{-1}$ kadmiyum konsantrasyonunda kontrol ile karşılaştırıldığında önemli ölçüde azalmıştır. Kadmiyum uygulanan larvaların lipit miktarı, 50 ve $200 \mathrm{mg} \mathrm{kg} \mathrm{kg}^{-1} \mathrm{kadmiyum}$ konsantrasyonlarında çok değişmediği halde, $100 \mathrm{mg} \mathrm{kg}^{-1}$ da önemli ölçüde düşmüştür.
\end{abstract}

(c) OMU ANAJAS 2021
The Interaction of Cadmium with Protein, Lipid and Carbohydrate Concentrations in Lesser Wax Moth Larvae

\section{ABSTRACT}

The influence of cadmium on protein, lipid and carbohydrate levels of lesser wax moth, Achroia grisella Fabricius, 1794 (Lepidoptera:Pyralidae) larvae was examined under laboratory conditions. Larvae were reared on an artificial diet medium contaminated with three different concentrations of cadmium (50, 100 and $200 \mathrm{mg} \mathrm{kg}^{-1}$ diet). In the control group the insects fed on cadmium-free diet containing honeycomb (200 g), bran (860 g), glycerol (300 ml), honey (150 ml) and distilled water (150 $\mathrm{ml}$ ). All of the insects were kept at $25 \pm 2{ }^{\circ} \mathrm{C}$ temperature, $60 \pm 5 \%$ relative humidity and 16L:8D photoperiod conditions. Last instar $A$. grisella larvae were weighed, placed individually into microcentrifuge tubes and stored at $-20{ }^{\circ} \mathrm{C}$ for the biochemical analysis. The results of this study showed that cadmium contamination caused a significant reduction in the protein level of the larvae at 50 and $200 \mathrm{mg} \mathrm{kg}^{-1}$ concentrations. Carbohydrate level reduced significantly at only $50 \mathrm{mg} \mathrm{kg}^{-1}$ cadmium concentration compared with control. Lipid level of the cadmium-treated larvae considerably reduced ${ }^{1}$ at $100 \mathrm{mg} \mathrm{kg}^{-1}$ concentration, while it remained more or less unaffected at 50 and $200 \mathrm{mg} \mathrm{kg}^{-1}$

Anahtar Sözcükler: Achroia grisella Biyokimyasal kompozisyon Ağır metal

Keywords:

Achroia grisella

Biochemical

composition

Heavy metal cadmium concentrations. 


\section{Giriş}

Günümüzde insan sağlığını tehdit eden en önemli tehlikelerden biri çevre kirliliğidir. Ağır metaller çevre kirliliğine sebep olan en önemli faktörler arasındadır. Bunlar, çok çeşitli kaynaklardan ortaya çıkabilmeleri, kolaylıkla besin zincirine girerek canlıların yapılarında birikmeleri nedeniyle diğer doğal ve kimyasal kirleticiler arasında önemli bir yere sahiptir (Kayış ve Emre, 2012). Ağır metaller çok eski zamanlardan günümüze kadar insanlar tarafından farklı amaçlarla işlenmiş ve kullanılmıştır. Madencilik, demir-çelik sanayi, cam ve seramik sanayi, kağıt endüstrisi, petrokimya sanayi, enerji üretimi ve gübre üretimi gibi günümüzün önemli endüstriyel faaliyetleri ağır metallerin en çok kullanıldığı alanlardır. Bu endüstriyel faaliyetlerin kontrolsüz devamı ve bunun yanında imha edilmek yerine doğaya atılan şehirsel atıklar ağır metal kirliliğini hızla artırmıştır (Yavuz ve Sarıgül, 2016).

Daha önce yapılan bazı çalışmalarda ağır metallerin böceklerin değişik özellikleri üzerindeki etkileri araştııılmıştır. Raina ve ark. (2001), Musca domestica (Diptera: Muscidae) larvalarını 6 farklı ağır metale maruz bırakarak post embriyonik gelişim ve ergin çıkışının olumsuz etkilendiğini ayrıca ağır metal uygulanan larvalardan elde edilen neslin üreme potansiyelinin de oldukça azaldığını belirlemişlerdir. Borowska ve ark. (2004) bakır, çinko, kurşun ve kadmiyum ile kontamine edilen yapay besin ortamında yetiştirilen $M$. domestica larvalarında, ağır metallerin vücutta biriktiğini ve bu birikmenin larval gelişimi, metamorfozu, larva ve pupların hayatta kalma oranını olumsuz etkilediğini göstermişlerdir. Aynı çalışmada ağır metallerin toplam hemosit sayısını ve hemositlerin adhezyon yeteneklerini de azalttığını belirtmişlerdir. Filipiak ve ark. (2010) çinko uygulamasının M. domestica ve Drosophila melanogaster (Diptera:Tephritidae) türlerinde fagositozu arttırdığını ve programlanmış hücre ölümünü etkilediğini göstermişlerdir. Mırčıć ve ark. (2010) üç farklı konsantrasyonda kadmiyum çözeltisi kullanarak, kadmiyumun çingene güvesinde larva süresini değiştirmediğini, pup süresini kısalttığını ve pup büyüklügünü azalttığını belirlemişlerdir. Shakunthala ve Shalini (2018) kurşun asetat ve çinko klorürün sublethal konsantrasyonlarının D. melanogaster türünde ömür uzunluğunu azalttığını belirlemişlerdir. Ayrıca Suganya ve ark. (2016) kadmiyum ve kurşunun Spodoptera litura (Lepidoptera: Noctuidae) larvaları üzerinde toksik etkisi olduğunu ve antioksidan enzim faaliyetlerinde önemli bir artışa neden olduğunu gözlemlemişlerdir. El-Sheikh ve ark. (2010) yaptıkları çalışmada Culex pipiens L. (Diptera: Culicidae) larvalarının ölüm yüzdesinin ağır metal konsantrasyonundaki artışa bağlı olarak arttığını göstermişlerdir. Başka bir çalışma da Gao ve ark. (2012) kadmiyumun tahıl biti, Sitobion avena Fabricius (Hemiptera: Aphididae)'un hayatta kalma ve üreme özelliklerini olumsuz etkilediğini tespit etmişlerdir.

Küçük Balmumu Güvesi olarak bilinen, Achroia grisella (Fabricius, 1794) (Lepidoptera: Pyralidae) arı kovanlarına ciddi zarar veren ve bal arısı populasyonlasyonlarını tehdit eden kozmopolit bir zararlı türüdür (Mahgoup ve ark., 2015). Özellikle zayıflamış kovanlarda güvelerin daha zararlı olduğu bilinmektedir. Bal arılarının olduğu hemen hemen her yerde bulunabilirler ve dişiler normal koşullarda yumurtalarını bal kovanlarının içindeki yarıklara bırakırlar. Gelişmekte olan larvalar polen, bal ve balmumu ile beslenir, bu nedenle arıcılık endüstrisinde ağır ekonomik hasara neden olurlar. Gelişim süresinin kısa olması, kolay üretilebilmesi ve üzerinde çeşitli parazitoit ve predatörlerin yetişmesine olanak tanıması gibi nedenlerle A. grisella türünün biyolojisi, davranış özellikleri ve kontrolü konusunda bazı çalışmalar yapılmıştır (Greenfield ve Coffelt, 1983; Nurullahoğlu, 2003). A. grisella ayrıca böcek fizyolojisi, genomik ve proteomik araştırmalarda da model organizma olarak kullanılmıştır (Ellis ve ark., 2013; Mahgoup ve ark., 2015; Gleason ve ark., 2016; Çelik ve ark., 2017). A. grisella'nın farklı özellikleri ile ilgili olarak yapılan bu çalışmalar bazı önemli bilgiler sağlamış olmasına rağmen, kadmiyumun A. grisella larvalarının protein, karbohidrat ve lipit miktarı üzerindeki etkileri çok iyi bilinmemektedir. Bu nedenle bu çalışmada oldukça toksik bir ağır metal olan kadmiyumun A. grisella larvalarının protein, karbohidrat ve lipit miktarlarına etkileri araştırılmıştır.

\section{Materyal ve Yöntem}

\section{1 . Küçük balmumu güvesi kültürlerinin hazırlanması}

Denemelerde Küçük Balmumu Güvesi, A. grisella'nın son evre larvaları kullanılmıştır. Larvaların beslenmesinde Sak ve ark. (2006)'nın Bronskill (1961) besininde düzenleme yaparak elde ettikleri petek, kepek, bal, gliserol ve saf sudan oluşan karışım kullanıldı. Hazırlanan besin yarım litre hacmindeki cam kavanozlara konularak kavanozların her birine 10-15 adet A. grisella ergini ilave edildi ve kavanozların üst kısımları böceklerin kaçmasını engellemek için hava sirkülasyonunu önlemeyecek şekilde uygun bir bez parçası ile kapatıldı. Hazırlanan

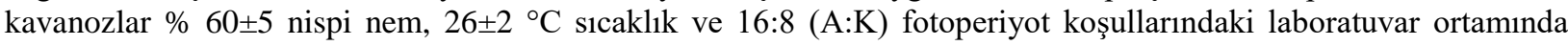


bekletildi. Böylece A. grisella stok kültürleri oluşturuldu. Kadmiyumun larvaların protein, lipit ve karbohidrat miktarlarına etkisini belirlemek için önce 2000 ppm kadmiyum içeren stok çözelti hazırlandı. Bu stok çözelti kullanılarak hazırlanan farklı konsantrasyondaki kadmiyum çözeltileri 50,100 ve $200 \mathrm{mg} \mathrm{kg}^{-1}$ olacak şekilde $A$. grisella besinine ilave edildi. Hazırlanan besinlerden yarım litrelik cam kavanozlara yeterince konulup, her kavanoza 10-15 adet A. grisella ergini yerleştirildi. Bu kavanozlardan elde edilen son evre larvalar tartılarak -20 ${ }^{\circ} \mathrm{C}$ 'de stoklandı ve biyokimyasal analizlerde kullanıldı. Kontrol grubunun oluşturulmasında ise besine kadmiyum ilave edilmedi ve stok kültürlerin hazırlanmasında kullanılan besin içeriğinin aynısı kullanıldı.

\section{2. Biyokimyasal analizler}

Larvalardaki protein miktarının belirlenmesinde Lowry ve ark. (1951)'nın yöntemi kullanıldı. Bunun için tartıldıktan sonra $-20^{\circ} \mathrm{C}$ 'de stoklanan larva örnekleri dondurucudan çıkarılarak $500 \mu$ l tampon çözeltide homojenize edildi. Bu homojenatlar tamponla $1000 \mu$ l ye tamamlanarak $+4^{\circ} \mathrm{C}$ 'de 3500 devir/dakikada 15 dakika santrifüj edildi. Süpernatanttan $100 \mu \mathrm{l}$ alınarak üzerine $900 \mu \mathrm{l}$ tampon ilave edildi, böylece örneklerde 10 kat sulandırma yapıldı. Sulandırılan örneklerden $100 \mu 1$ alınarak Lowry metodu uygulandı. Hazırlanan numunelerin absorbans değerleri 695 nm dalga boyunda okundu. Elde edilen absorbans değerleri sığır serum albumin çözeltisi kullanılarak hazırlanan standart protein grafiğinde bulunan değerler ile karşılaştırılarak larvalardaki protein miktarı belirlendi.

Larvalarda lipit ve karbohidrat miktarının belirlenmesi için, daha önce farklı araştırıcılar (Olson ve ark., 2000; Fadamiro ve Heimpel, 2001; Lee ve ark., 2004) tarafindan kullanılan van Handel (1985a ve 1985b)'den modifiye edilmiş yöntemlerden yararlanıldı. Karbohidrat ve lipit miktarının belirlenmesi için, $-20{ }^{\circ} \mathrm{C}$ 'de mikrosantrifüj tüplerinde bekletilen larvalar dondurucudan çıkarıldı. Her bir mikrosantrifüj tüpüne $100 \mu \mathrm{l} \% 2$ 'lik sodyum sülfat çözeltisi ilave edilerek larvalar homojenize edildi. Homojenatlara $900 \mu$ l kloroform-metanol (1:2) karışımı eklenerek karıştırıldı. Karışım 14000 devir/dakikada 2 dakika santrifüj edildi. Santrifüj işlemi sonunda oluşan süpernatanttan $100 \mu \mathrm{l}$ alınarak bir tüpe aktarıldı ve kloroform-metanol (1:2) karışımı ile 10 kat daha sulandırıldı. Bu karışımdan $100 \mu \mathrm{l}$ alınarak karbohidrat analizinde, diğer $100 \mu \mathrm{l}$ ise lipit analizinde kullanıldı.

Karbohidrat analizi için, içerisinde $100 \mu \mathrm{l}$ numune bulunan tüp $90{ }^{\circ} \mathrm{C}$ sicaklıktaki su banyosunda yaklaşık $50 \mu 1$ çözelti kalana kadar bekletildi. Tüp içerisinde kalan çözelti üzerine $950 \mu \mathrm{l}$ antron reaktifi eklendikten sonra tüpler tekrar $90{ }^{\circ} \mathrm{C}$ 'deki su banyosuna yerleştirildi ve 15 dakika bekletildi. Tüpteki örneğin absorbans değeri $625 \mathrm{~nm}$ dalga boyunda okunarak, farklı konsantrasyonda glukoz çözeltileri kullanılarak hazırlanan standart karbohidrat grafiği ile karşılaştırıldı ve larvalardaki karbohidrat miktarı belirlendi.

Lipit analizi için, içerisinde $100 \mu \mathrm{l}$ çözelti bulunan tüp çözeltinin tamamı buharlaşıncaya kadar $90^{\circ} \mathrm{C}$ 'deki su banyosunda 1 sıtıldı. Tüpte kalan lipit kalıntısına $40 \mu \mathrm{l}$ konsantre sülfürik asit çözeltisi ilave edilerek tüpler karıştırıldı ve $90{ }^{\circ} \mathrm{C}$ sıcaklıktaki su banyosunda 2 dakika bekletildi. Su banyosundan çıkarılan tüp buzda soğutularak üzerine $960 \mu \mathrm{l}$ vanilin-fosforik asit reaktifi ilave edildi ve 30 dakika oda sıcaklığında bırakıldı. Renk değişimi gözlenen örneklerin absorbans değerleri $525 \mathrm{~nm}$ dalga boyunda okundu. Lipit standardı olarak mısır yağ çözeltisi kullanıldı. Okunan absorbans değerleri standart lipit grafiğindeki değerlerle karşılaştırılarak larvalardaki lipit miktarı belirlendi.

\section{3. Elde edilen verilerin istatistiksel olarak değerlendirilmesi}

Kadmiyumun A. grisella larvalarının protein, karbohidrat ve lipit miktarlarına etkisi ile ilgili sonuçların değerlendirilmesinde ikiden fazla grubun karşılaştırılmasında tek yönlü varyans analizi (ANOVA) kullanıldı. Bu testten elde edilen sonuçların önem seviyeleri Student-Newman-Keuls (SNK testi) kullanılarak değerlendirildi. Değerlendirmelerde 0.05 güven sınırı $(\mathrm{P})$ esas alındı. $\mathrm{P}>0.05$ ise ortalamalar arasındaki fark önemsiz, $\mathrm{P} \leq 0.05$ ise fark önemli olarak kabul edildi.

\section{Bulgular ve Tartışma}

Kadmiyumun A. grisella larvalarının protein miktarına etkisine ilişkin sonuçlar Şekil 1'de gösterilmiştir. Şekil 1 incelendiğinde, kadmiyum uygulamasının larvaların protein miktarını azalttığı görülmektedir. Azalma oranı 50 ve $200 \mathrm{mg} \mathrm{kg}^{-1}$ kadmiyum içeren gruplarda kontrol grubuna göre istatistiksel açıdan önemli iken, $100 \mathrm{mg} \mathrm{kg}^{-1}$ olan grupta önemli değildir. 


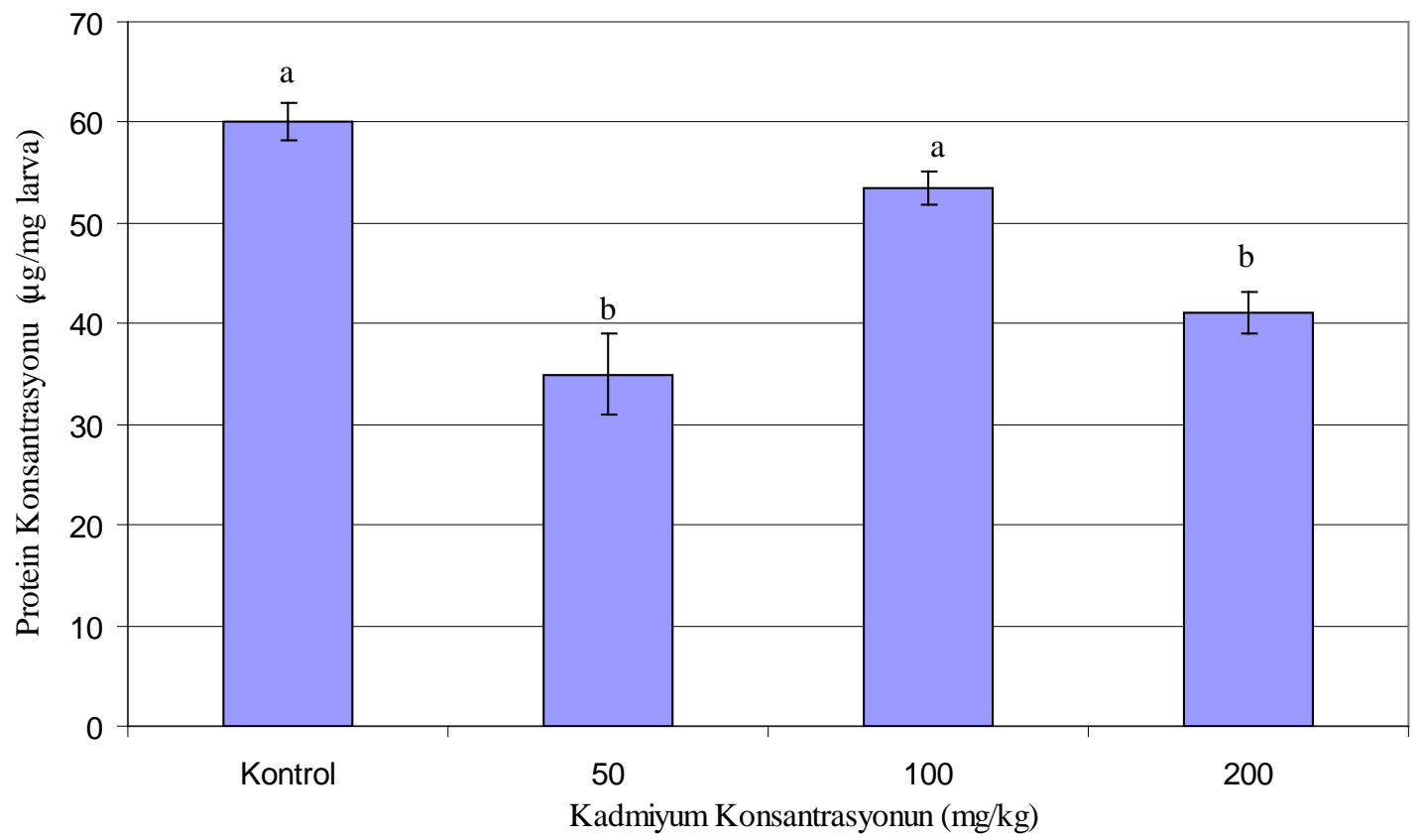

Şekil 1. Kadmiyumun A. grisella larvalarının protein miktarına etkisi. Farklı harflerle gösterilen ortalamalar arasındaki fark önemlidir (SNK testi, $\mathrm{F}=19.463, \mathrm{df}=3,76, \mathrm{P}=0.000$ )

Figure 1. Effect of cadmium on protein composition of A. grisella larvae. Means followed by different letters are significantly different (SNK test, $F=19.463, d f=3,76, P=0.000$ )

Kadmiyum uygulaması sonucunda A. grisella larvalarının protein miktarında görülen azalma farklı araştırıcıların çalışmaları ile benzerlik göstermektedir. Emre ve ark. (2013) yüksek konsantrasyonda kadmiyum (20 ve $40 \mathrm{mg} \mathrm{kg}^{-1}$ ) uygulamasının G. mellonella (Lepidoptera:Pyralidae) larvalarında toplam protein miktarını önemli ölçüde azalttığını göstermişlerdir. Benzer sonuçlar Chrysochoris stolli (Hemiptera: Scutelleridae) (Islam ve Roy, 1983), P. turionellae (Hymenoptera: Ichneumonidae) (Ortel, 1991), ve Boettcherisca peregrina (Diptera: Sarcophagidae) (Wu ve ark., 2006) türlerinde yapılan çalışmalarda da elde edilmiştir. Protein miktarındaki azalma, Norton ve Kench (1977) tarafindan ileri sürüldüğü gibi doğrudan protein sentezinin inhibe edilmesinden ya da Sancho ve ark. (1998)'nın belirttiği gibi toksik maddelerin neden olduğu zararların giderilmesinde kullanılan lipoprotein miktarındaki azalmadan kaynaklanmış olabilir. Bulgularımızın aksine, Baghban ve ark. (2014) çalışmalarında kullandıkları tüm bakır konsantrasyonlarında $\left(25,50\right.$ ve $100 \mathrm{mg} \mathrm{kg}^{-1}$ besin) ve düşük çinko konsantrasyonlarında (25 ve $50 \mathrm{mg} \mathrm{kg}^{-1}$ besin) Helicoverpa armigera (Lepidoptera: Noctuidae)'nın 3. evre larvalarında protein miktarının arttığını göstermişlerdir.

Ağır metallerin protein miktarı üzerindeki etkileri kullanılan böcek türüne, eşeyine, böceğin maruz kaldığı ağır metal tipine, konsantrasyonuna ve maruz kalma süresine göre farklılık gösterebilir. Kayış ve Emre (2012), besine ilave edilen kadmiyumun $P$. turionellae dişilerinde genel olarak protein miktarını azalttığını ancak bazı günlerde (30. gün) özellikle düşük kadmiyum konsantrasyonlarında protein miktarının kontrol grubuna göre artış gösterdiğini belirlemişlerdir. Hassan ve ark. (2011) kadmiyum, bakır, kurşun ve civa uygulamasının C. pipiens dişilerinde toplam protein miktarını azalttığını, buna karşın aynı türün bakır, kurşun ve civa uygulanan erkeklerinde proteinin artı̧̧ gösterdiğini belirlemişlerdir. Ağır metaller aynı böcek türünün hemolenf ve toplam vücut proteinleri üzerinde de farklı etki gösterebilirler. Bischof (1996), Glyptapanteles liparidis (Hymenoptera: Braconidae) tarafindan parazitlenen ve kadmiyum, kurşun, bakır ya da çinko ile kontamine edilen besin ortamında yetiştirilen Lymantria dispar (Lepidoptera: Lymantriidae) larvalarının hemolenf protein konsantrasyonunun tüm kontamine olan gruplarda önemli ölçüde azaldığını, ancak toplam vücut proteinlerinin arttığını göstermiştir.

Larvalara besin içerisinde kadmiyum verilmesinin karbohidrat miktarına etkileri Şekil 2'de gösterilmiştir. Şekilde sadece $50 \mathrm{mg} \mathrm{kg}^{-1}$ kadmiyum içeren grupta karbohidrat miktarının kontrol grubuna oranla önemli ölçüde azaldığı görülmektedir. Buna karşın 100 ve $200 \mathrm{mg} \mathrm{kg}^{-1}$ kadmiyum içeren besinle beslenen gruplarda karbohidrat miktarı kontrol grubu ile benzer bulunmuştur. 


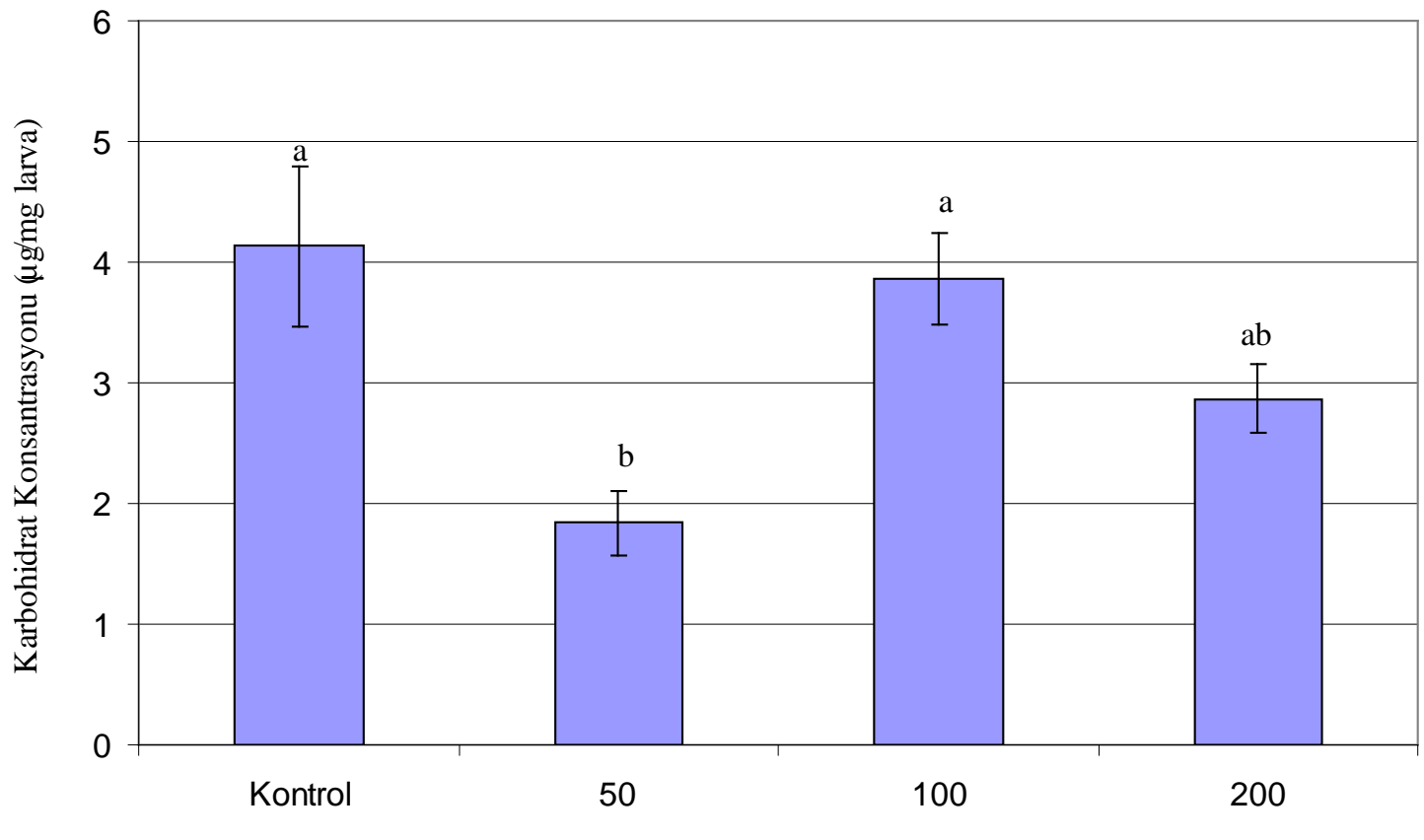

Kadmiyum Konsrasyonu (mg/kg)

Şekil 2. Kadmiyumun A. grisella larvalarının karbohidrat miktarına etkisi. Farklı harflerle gösterilen ortalamalar arasındaki fark önemlidir ( $\mathrm{SNK}$ testi, $\mathrm{F}=5.820, \mathrm{df}=3,76, \mathrm{P}=0.001$ )

Figure 2. Effect of cadmium on carbohydrate composition of A. grisella larvae. Means followed by different letters are significantly different (SNK test, $F=5.820, d f=3,76, P=0.001$ )

Bischof (1995), G. liparidis tarafından parazitlenmiş L. dispar larvalarının hemolenfindeki trehaloz konsantrasyonunun kadmiyum kontaminasyonu ile, vücut dokularındaki glikojen konsantrasyonunun da kadmiyum ve çinko kontaminasyonu ile azaldığını belirlemiştir. Benzer olarak, Bream (2003) üç farklı kurşun nitrat ve bakır sülfat konsantrasyonuna (10, 20 ve $30 \mathrm{mM}$ ) maruz birakılan sucul böcek türü Sphaerodema urinator (Hemiptera: Belostomatidae)'da karbohidrat miktarının azaldığını göstermiştir. El-Sheikh ve ark. (2010) kadmiyum klorür veya civa nitrat verilen larvalardan elde edilen erkek ve dişi C. pipiens erginlerinde toplam karbohidrat içeriğinin dikkate değer şekilde azaldığını ifade etmişlerdir. George (1982) çinko, demir, manganez, kadmiyum ve çinko gibi birçok metal katyonların kalsiyum ile birlikte mitokondri içinde biriktiğini; Viarengo (1985) ise mitokondride çok düşük konsantrasyonda bile olsalar bu metallerin oksidatif fosforilasyonu inhibe ettiklerini göstermiştir. Spring ve ark. (1977) ise karbohidrat miktarında belirlenen azalmanın glikoneolitik sürecin hızlanması ile ilişkili olabileceğini ifade etmiştir. Farklı araştıııcıların çalışmaları sonucunda elde ettikleri bu bulgular A. grisella larvalarının karbohidrat miktarlarında görülen azalmanın nedenini açıklamak için yardımcı olabilir. Bununla birlikte, Wu ve ark. (2006) B. peregrina türünde yüksek konsantrasyonda kadmiyum uygulamasının hemolenfdeki toplam şeker miktarını arttırdığını göstermiştir. Kayış ve Emre (2012) ise P. turionellae dişilerinde glikojen miktarının kadmiyum uygulamasından sonra arttı̆̆ını göstermişlerdir. Metal kontaminasyonun aynı böcek türü üzerindeki etkisi metal tipine ve konsantrasyonuna bağlı olarak değişiklik gösterebilir. Örneğin, Ortel (1996) L. dispar larvalarının hemolenfinde metal kontaminasyonunun trehaloz miktarını düşürdüğünü göstermiştir. Aynı çalışmada larvaların vücut dokularında bulunan glikojen içeriğinin düşük kadmiyum, kurşun ve bakır konsantrasyonlarında arttığı, yüksek kadmiyum ve her iki (yüksek ve düşük) çinko konsantrasyonunda azaldığı belirlenmiştir.

Farklı kadmiyum konsantrasyonlarının A. grisella larvalarının lipit miktarına etkisiyle ilgili sonuçlar Şekil 3'de gösterilmiştir. Kontrol grubundaki larvaların ortalama lipit miktarı $49.42 \pm 4.32 \mu \mathrm{g} \mathrm{mg}^{-1}$ olarak belirlenmiştir. Kadmiyum ilavesi larvaların lipit miktarında azalmaya neden olmuş, ancak sadece $100 \mathrm{mg} \mathrm{kg}^{-1}$ kadmiyum içeren gruptaki azalma oranının istatistiksel açıdan önemli olduğu belirlenmiştir. Buna karşın 50 ve $200 \mathrm{mg} \mathrm{kg}^{-1} \mathrm{kadmiyum}^{-}$ içeren gruplardaki larvaların lipit miktarları kontrol grubundakilerden istatistiksel açıdan farksız bulunmuştur. 


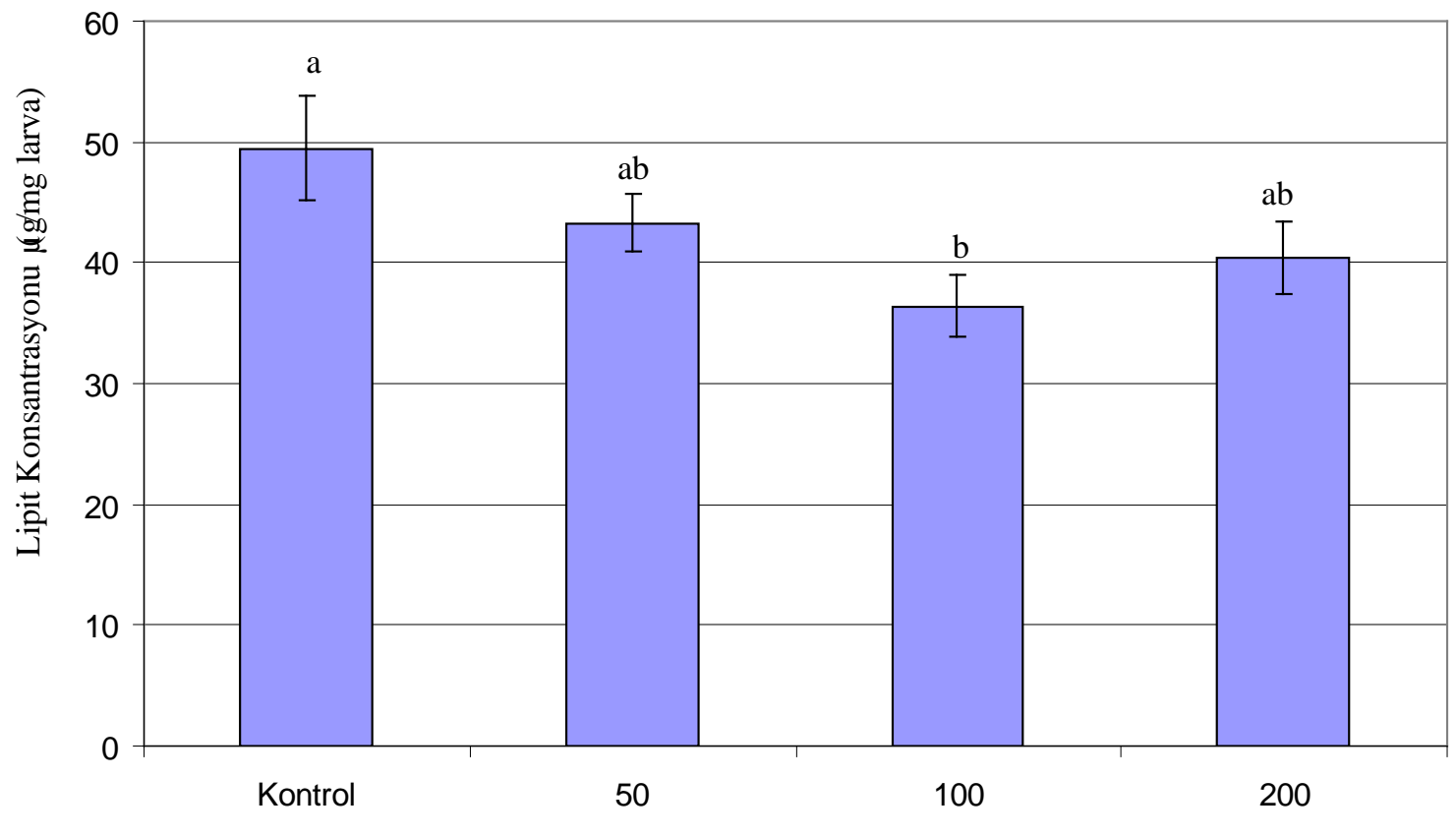

Kadmiyum Konsantrasyonu (mg/kg)

Şekil 3. Kadmiyumun A. grisella larvalarının lipit miktarına etkisi. Farklı harflerle gösterilen ortalamalar arasındaki fark önemlidir (SNK testi, $\mathrm{F}=2.997, \mathrm{df}=3,76, \mathrm{P}=0.036$ )

Figure 3. Effect of cadmium on lipid composition of A. grisella larvae. Means followed by different letters are significantly different (SNK test, $F=2.997, d f=3,76, P=0.036$ )

Metal kontaminasyonu sonucunda lipit miktarında görülen azalma C. stolli (Islam ve Roy, 1983), P. turionellae (Ortel, 1991), L. dispar (Bischof, 1995; Ortel, 1995) ve G. mellonella (Shin ve ark., 2001) gibi böcek türleri ile yapılan çalışmalarda da belirlenmiştir. Lipit miktarında belirlenen azalma, ağır metal stresi altında enerji ihtiyacının artışı ve böceğin bu ihtiyacı karşılayabilmek için lipitleri diğer enerji kaynaklarını desteklemek amacıyla kullanmış olması ile açıklanabilir. Ağır metal kontaminasyonunun aynı türün lipit miktarı üzerindeki etkisi eşeyler arasında farklılık gösterebilir. El-Sheikh ve ark. (2010) C. pipiens dişilerinde bakır sülfat ve civa nitratın toplam lipit miktarını azalttığını, erkeklerde ise bakır sülfat ve kurşun nitratın lipit miktarını artırdığını tespit etmiştir.

\section{Sonuç}

Böcekler ekosistemde diğer birçok canlı türü tarafından besin kaynağı olarak kullanılmaktadır. Ağır metal kirliliğinin fazla olduğu yerlerde yaşayan böcekler bu ağır metalleri değişik yollarla vücutlarına alarak biriktirebilirler. Böcek vücudunda biriken ağır metaller besin zinciri yoluyla ekosistemdeki diğer organizmalara geçerek onların bazı hayatsal fonksiyonlarını etkiler.

Bu çalışmada zararlı bir tür olan A. grisella larvalarının besinine farklı konsantrasyonlarda kadmiyum eklenerek, kadmiyumun larvaların vücut dokularında bulunan protein, lipit ve karbohidrat miktarlarına etkileri araştırılmıştır. Elde edilen sonuçlar genel olarak değerlendirildiğinde, kadmiyumun protein, lipit ve karbohidrat miktarlarını azalmaya neden olduğu, ancak bazı gruplarda belirlenen azalma oranının istatistiksel açıdan önemsiz olduğu görülmektedir. Elde edilen sonuçlar bazı araştırıcıların çalışmalarıyla benzerlik gösterirken, diğer bazılarının sonuçlarından farklı bulunmuştur. Bu durumun nedeni, ağır metallerin etkilerinin çalışmalarda kullanılan böcek türüne, böceğin gelişim evresine, eşeyine, ağır metal türüne, konsantrasyonuna, uygulama yöntemi ve süresine göre farklılık göstermesidir. Böceğin biyokimyasal kompozisyonunun ağır metal kullanımı sonucunda az ya da çok değişmiş olması onun gelişimden üremeye birçok fizyolojik faaliyetini etkileyecektir. Bu nedenle ileri de yapılacak çalışmalarda ağır metallerin A. grisella türünün biyolojik ve fizyolojik özellikleri üzerindeki etkilerinin ayrı ayrı ve daha detaylı şekilde değerlendirilmesi yararlı olacaktır. 


\section{Kaynaklar}

Baghban, A., Sendi, J.J., Zibaee, A. and Khosravi, R., 2014. Effect of heavy metals (Cd, Cu, and Zn) on feeding indices and energy reserves of the cotton boll worm Helicoverpa armigera Hübner (Lepidoptera: Noctuidae). Journal of Plant Protection Research, 54(4): 368-371. doi: 10.2478/jppr-2014-0055.

Bischof, C., 1995. Effects of heavy metal stress on carbohydrate and lipid concentrations in the haemolymph and total body tissue of parasitized Lymantria dispar L. Larvae (Lepidoptera). Comparative Biochemistry and Physiology Part C: Pharmacology, Toxicology and Endocrinology, 112(1): 87-92. https://doi.org/10.1016/07428413(95)00079-8.

Bischof, C., 1996. Effects of heavy metal stress on free amino acids in the haemolymph and proteins in haemolymph and total body tissue of Lymantria dispar larvae parasitized by Glyptapanteles liparidis. Entomologia Experimentalis et Applicata, 79(1): 61-68. https://doi.org/10.1111/j.1570-7458.1996.tb00809.x.

Borowska, J., Sulima, B., Niklinska, M. and Pyza, E., 2004. Heavy metal accumulation and its effects on development, survival and immuna-competent cells of the housefly Musca domestica from closed laboratory populations as model organism. Fresenius Environmental Bulletin, 13: 1402-1409.

Bream, A.S., 2003. Laboratory evaluation of heavy metals stress on certain biochemical parameters of the aquatic insect, Sphaerodema urinator Duf. (Hemiptera: Belostomatidae). Communications in Agricultural and Applied Biological Sciences, 68(4): 291-297.

Bronskill, J.K., 1961. A cage to simplify the rearing of the greater wax moth, Galleria mellonella (Pyralidae). The Journal of the Lepidopterist's Society, 15: 102-104.

Çelik, D., Özbek, R. ve Uçkan, F., 2017. Effects of indole-3-acetic acid on hemocytes of Achoria grisella Fabr. (Lepidoptera: Pyralidae). Journal of Entomological Research Society, 19(2): 83-93.

Ellis, D.J., Graham, R.J. and Mortensen, A., 2013. Standard methods for wax moth research. Journal of Apicultural Research, 52(1): 1-17. https://doi.org/10.3896/IBRA.1.52.1.10.

El-Sheikh, Tarek M.Y., Hassan, M.I., Fouda Abd-Elghaphar, A.A. and Hasaballah, A.I., 2010. Toxicological effects of some heavy metal ions on Culex pipiens L.(Diptera:Culicidae). Egyptian Academic Journal of Biological Sciences, 1: 63-76. doi:10.21608/eajbsf.2010.17465.

Emre, İ., Kayış, T., Coşkun, M., Dursun, O. and Cogun, H.Y., 2013. Changes in antioxidative enzyme activity, glycogen, lipid, protein and malondialdehyde content in cadmium-treated Galleria mellonella larvae. Annals of the Entomological Society of America, Physiology, Biochemistry and Toxicology, 106(3): 371-377. doi: 10.1603/AN12137.

Fadamiro, H.Y. and Heimpel, G.E., 2001. Effects of partial sugar deprivation on lifespan and carbohydrate mobilization in the parasitoid Macrocentrus grandii (Hymenoptera: Braconidae). Annals of Entomological Society of America, 94(6): 909-916. https://doi.org/10.1603/0013-8746(2001)094[0909:EOPSDO]2.0.CO;2.

Filipiak, B., Bilska, B., Tylko, G. and Pyza, P., 2010. Effects of zinc on programmed cell death of Musca domestica and Drosophila melanogaster blood cells. Journal of Insect Physiology, 56: 383-390. doi: 10.1016/j.jinsphys.2009.11.010.

Gao, H.H., Zhao, H.Y., Du, C., Deng, M.M., Du, E.X., Hu, Z.Q and Hu, X.S., 2012. Life table evaluation of survival and reproduction of the aphid, Sitobion avenae, exposed to cadmium. Journal of Insect Sciences, 12 (44):44. doi: 10.1673/031.012.4401.

George, S.G., 1982. Subcellular accumulation and detoxification of metals in aquatic animals. In:Vernberg, W.B., Calabrese, A., Thurberg, F.P.,Vernberg, F.J. (Eds.), Physiological Mechanisms of Marine Pollutant Toxicity. Academic Press, 3-52, New York.

Gleason, J.M., Zhou, Y., Hackett, J.L., Haris, B.R. and Greenfield, M.D., 2016. Development of a genomic resource and quantitative trait loci mapping of male calling traits in the lesser wax moth, Achroia grisella. PLoS ONE 11:1. https://doi.org/10.1371/journal.pone.0147014.

Greenfield, M.D. and Coffelt, J.A., 1983. Reproductive behaviour of the lesser wax moth, Achroia grisella (Pyralidae: Galleriinae): signalling, pair formation, male interactions, and mate guarding. Behaviour, 84: 287315. https://doi.org/10.1163/156853983X00534.

Hassan, M.I., Fouda, M.A., El-Sheikh, Tarek, M.Y., Abd-Elghaphar, A.A. and Hasaballah, A. I., 2011. Electrophoretic study of ovarian protein and amino acid in the mosquito Culex pipiens L. (Diptera: Clucidae) as influenced by some heavy metal ions. Egyptian Journal of Biomedical Sciences, 36: 1-14.

Islam, A. and Roy, S., 1983. Effects of $\mathrm{CdCl}_{2}$ on the quantitative variations of carbohydrate, protein, amino acid and cholesterol in Chrysochoris stolli Wolf. (Insecta: Hemiptera). Current Sciences, 52: 215-217.

Kayış, T. ve Emre, İ., 2012. Ağır metal stresinin Pimpla turionellae (Hymenoptrea: Ichneumonidae)'nin protein ve glikojen sentezine etkileri. Ekoloji, 21(83): 61-67. doi: https://doi.org/10.5053/ekoloji.2012.837. 
Lee, J.C., Heimpel, G. E. and Leibee, G.L., 2004. Comparing floral nectar and aphid honeydew diets on the longevity and nutrient levels of a parasitoid wasp. Entomologia Experimentalis et Applicata, 111(3): 189-199. https://doi.org/10.1111/j.0013-8703.2004.00165.x.

Lowry, O.H., Rosebrough, N.J., Farr, A.L. and Randall, R.J., 1951. Protein measurement with the folin-phenol reagent. The Journal of Biological Chemistry, 193: 265-275. doi:https://doi.org/10.1016/S0021-9258(19)524516.

Mahgoup, M.O., Lau, W.H. and Bin Omar, D., 2015. Observations on the biology and larval instars discrimination of wax moth Achroia grisella F. (Pyralidae: Lepidoptera). Journal of Entomology, 12(1): 1-11. doi:10.3923/je.2015.1.11.

Mırčıć, D., Jankovic-Tomanıc, M., Nenadovic, V., Franeta, F. and Lazarevic, J. 2010. The effect of cadmium on the life history traits of Lymantria dispar L. Archives of Biological Sciences Belgrade, 62(4): 1013-1020. doi: 10.2298/ABS1004013M.

Norton, K.B. and Kench, J.E., 1977. Effects of cadmium on ribosomal protein synthesis in rat liver. Environmental Research, 13: 102-110.

Nurullahoğlu, Z.Ü., 2003. Achroia grisella (Lepidoptera:Pyralidae) larva ve pupunun yağ asidi bileşimi. Selçuk Üniversitesi, Fen- Edebiyat Fen Dergisi, 21: 75-78.

Olson, D.M., Fadamiro, H., Lundgren, J.G., Heimpel, G.E. 2000. Effects of sugar feeding on carbohydrate and lipid metabolism in a parasitoid wasp. Physiological Entomology, 25(1): 17-26. https://doi.org/10.1046/j.13653032.2000.00155.x.

Ortel, J., 1991. Effects of lead and cadmium on chemical composition and total water content of the pupal parasitoid, Pimpla turionellae. Entomologia Experimentalis et Applicata, 59: 93-100. https://doi.org/10.1111/j.1570-7458.1991.tb01491.x.

Ortel, J., 1995. Effects of metals on the total lipid content in the gypsy moth (Lymantria dispar, Lymantriidae, Lepid.) and its hemolymph. Bulletin of Environmental Contamination and Toxicology, 55: 216-221. doi: 10.1007/bf00203012.

Ortel, J., 1996. Metal-supplemented diets alter carbohydrate levels in tissue and hemolymph of gypsy moth larvae (Lymantria dispar, Lymantriidae, Lepidopter). Enviromental Toxicology and Chemistry, 17(7): 1171-1176. https://doi.org/10.1002/etc.5620150723.

Raina, M.R., Pawar, P. and Sharma, N., 2001. Developmental inhibition and reproductive potential impairment in Musca domestica L. by heavy metals. Indian Journal of Experimental Biology, 39: 78-81.

Sak, O., Uçkan, F. and Ergin, E., 2006. Effects of cypermethrin on total body weight, glycogen,protein and lipid contents of Pimpla turionella (L.) (Hymenoptera: Ichneumonidae). The Belgian Journal of Zoology, 136: 53-58.

Sancho, E., Ferrando, D., Frenandez, C. and Andreu, E., 1998. Liver energy metabolism of Anguilla anguilla after exposure of fenirothion. Ecotoxicology and Environmental Safety, 41: 168-175. doi: 10.1006/eesa.1998.1689.

Shakunthala, V. and Shalini H.K., 2018. Combined effect of heavy metals on longevity of Drosophila melanogaster. International Journal of Science and Research, 7(8): 1315-1318. doi: 10.21275/ART2019382.

Shin, B.S., Choi, R.N. and Lee, C-U., 2001. Effects of cadmium on total lipid content and fatty acids of the greater wax moth, Galleria mellonella. Korean Journal of Ecology, 24(6): 349-352.

Spring, J.H., Matthews, R. and Downer, A., 1977. Fate of glucose in the haemolymph of the American cockroach, Periplaneta americana. Journal of Insect Physiology, 23: 525-529. https://doi.org/10.1016/0022-1910(77)902645

Suganya, M., Karthi, S. and Shivakumar, M.S., 2016. Effect of cadmium and lead exposure on tissue specific antioxidant response in Spodoptera litura. Free Radicals and Antioxidants, 6(1): 90-100. doi: 10.5530/fra.2016.1.11.

Van Handel, E., 1985a. Rapid determination of glycogen and sugars in mosquitoes. Journal of the American Mosquito Control Association, 1: 299-301.

Van Handel, E., 1985b. Rapid determination of total lipids in mosquitoes. Journal of the American Mosquito Control Association, 1:302-304.

Viarengo, A., 1985. Biochemical effects of trace metals. Marine Pollution Bulletin, 16: 153-158. https://doi.org/10.1016/0025-326X(85)90006-2.

Yavuz, O. ve Sarıgül, N., 2016. Toprak ve sucul ortamlardaki ağır metal kirliliği ve ağır metal dirençli mikroorganizmalar. Mehmet Akif Ersoy Üniversitesi Fen Bilimleri Enstitüsü Dergisi, 7(1): 44-51 doi: 10.29048/makufebed.206609.

Wu, G. Ye, G. Hu, C. and Cheng, J., 2006. Accumulation of cadmium and its effects on growth, development and hemolymph biochemical compositions in Boettcherisca peregrina larvae (Diptera: Sarcophagidae). Insect Science, 13: 31-39. doi: 10.1111/j.1744-7917.2006.00065.x. 